
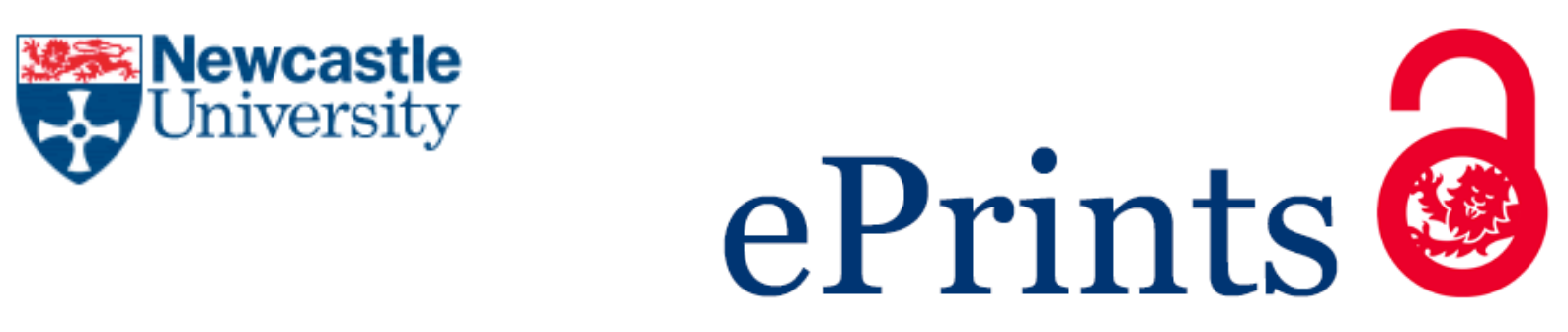

Burford B, Alberti H, Kennedy D. Early career intentions of medical students: are we selecting the graduates we need for the 21st century? Education for Primary Care 2017. DOI: 10.1080/14739879.2017.1362669

\title{
Copyright:
}

This is an Accepted Manuscript of an article published by Taylor \& Francis in Education for Primary Care on 17 August 2017, available online: https://doi.org/10.1080/14739879.2017.1362669.

DOI link to article:

https://doi.org/10.1080/14739879.2017.1362669

Date deposited:

$04 / 09 / 2017$

Embargo release date:

17 August 2018

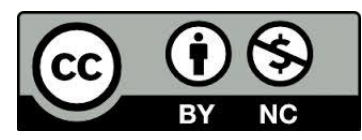

This work is licensed under a Creative Commons Attribution-NonCommercial 3.0 Unported License 


\section{Names of authors}

Bryan Burford

Hugh Alberti

David Kennedy

Institution (all authors)

School of Medical Education

Newcastle University,

Newcastle upon Tyne

NE1 7RU

United Kingdom

Corresponding author

Hugh Alberti

School of Medical Education

Newcastle University, Newcastle upon Tyne

Telephone: +44 (0) 1912085020 / Fax: +44 (0) 1912085016

Hugh.alberti@ncl.ac.uk

\section{Disclosure statement}

The authors report no conflicts of interest 
Dear Editor,

We would like to draw your readers' attention to the issue of early career intentions of medical students as it raises the vital question: Are we selecting the graduates we need for the 21st century? This concern was brought to national attention by the recent report "By choice - not by chance", jointly commissioned by Health Education England and the Medical Schools Council[1]. The report explored with key influential groups the factors within medical schools influencing general practice as a career choice. Previous work on the GP career preference of medical students at their time of entry to medical school have reported figures of $10-20 \%[2,3]$ but published reports are 10 years older and more; both the dynamic of medical careers and the workforce needs of the United Kingdom and beyond have changed dramatically over that time.

As part of a larger longitudinal study we are undertaking at one, large medical school, we asked a cohort of medical students to complete a paper questionnaire containing items on specialty preference on 3 occasions (early in year 1 , end of year 1 and end of year 2). At each time point, $90-92 \%$ of the year group responded: $n=193$ for the first 2 occasions and 206 (including those on the graduate entry programme) on the last occasion.

Our results showed that the majority of students at all time points reported "a fair idea but may change my mind" (43-46\%) or "several specialities appeal" (41-44\%). Much fewer had "no idea" (8-11\%) or had made a definite decision (0.5-5\%). The table below shows the students preferred career choice if known, i.e. if their response was that they had a definite decision or a fair idea. A proportion of students listed more than one career preference.

Table: Career preference reported by medical students (if known)

\begin{tabular}{|l|c|c|c|}
\hline \multicolumn{1}{|c|}{ Specialty } & $\begin{array}{c}\text { Year 1: October } \\
\mathbf{2 0 1 4}(\mathbf{n = 8 9})\end{array}$ & $\begin{array}{c}\text { Year 1: May } \\
\mathbf{2 0 1 5}(\mathbf{n = 9 3})\end{array}$ & $\begin{array}{c}\text { Year 2: May } \\
\mathbf{2 0 1 6}(\mathbf{n = 9 8 )}\end{array}$ \\
\hline Surgery & $34(38.2 \%)$ & $36(38.7 \%)$ & $30(30.6 \%)$ \\
\hline Medicine & $18(20.2 \%)$ & $20(21.5 \%)$ & $18(18.4 \%)$ \\
\hline Paediatrics & $14(15.7 \%)$ & $15(16.1 \%)$ & $16(16.3 \%)$ \\
\hline Emergency medicine & $9(10.1 \%)$ & $10(10.8 \%)$ & $10(10.2 \%)$ \\
\hline Psychiatry & $7(7.9 \%)$ & $9(9.7 \%)$ & $9(9.2 \%)$ \\
\hline General Practice & $5(5.6 \%)$ & $17(18.3 \%)$ & $21(21.4 \%)$ \\
\hline Anaesthetics & $5(5.6 \%)$ & $7(7.5 \%)$ & $10(10.2 \%)$ \\
\hline $\begin{array}{l}\text { Obstetrics and } \\
\text { gynaecology }\end{array}$ & $2(2.2 \%)$ & $8(8.6 \%)$ & $5(5.1 \%)$ \\
\hline Radiology & $2(2.2 \%)$ & $1(1.1 \%)$ & $3(3.1 \%)$ \\
\hline Other (please specify) & $6(6.7 \%)$ & $10(10.8 \%)$ & $7(7.1 \%)$ \\
\hline
\end{tabular}

The table illustrates that General Practice showed the largest increase in students' preferences over the first 2 years of their undergraduate studies. However, the striking figure is the extremely low proportion of students reporting a preference for General Practice at the beginning of year one; this is lower than previously reported figures $[2,3]$. Our data suggest that it is possible that the proportion of students being selected and recruited into medical schools with a preference towards a career in General Practice may be falling at the same time as the proportion of empty GP training places is increasing. This may be a local phenomenon, although historically our medical school has produced a similar proportion of graduates entering General Practice as the national average [4]. This could support the 
question raised by others [5] as to whether medical schools are recruiting the students that society requires for its future health needs. The increase in intention to General Practice over the two years is also notable and worthy of further exploration; interestingly, the figure of $21 \%$ with a GP career preference at the end of year 2 is very similar to the figure $(20 \%)$ reported for those at the beginning of final year at the same medical school over the last decade [6].

Medical career preferences have been addressed abundantly in the medical literature including systematic reviews $[7,8]$, indicating that medical career decision-making is a dynamic, complex and multifactorial issue. Recent publications have also explored the career intentions and attitudes to General Practice of final year medical students and young doctors $[9,10]$. However, if we are selecting and recruiting students with very low preferences towards General Practice, is it ever going to be an achievable goal for $50 \%$ of our graduates nationally to enter General practice training programmes? We would recommend that this problem be studied nationally and addressed urgently.

\section{References}

1. HEE/MSC. By choice - not by chance: supporting medical students towards future careers in General Practice. 2016. Available from: https://www.hee.nhs.uk/sites/default/files/documents/By\%20choice\%20not\%20by\%20chance\%20web\%20FI $\underline{\text { NAL.pdf }}$

2. Sinclair HK, Ritchie LD, Lee AJ. A future career in general practice? A longitudinal study of medical students and pre-registration house officers. Eur J Gen Pract. 2006;12:120-7.

3. Maudsley G, Williams L, Taylor D. Medical students' and prospective medical students' uncertainties about career intentions: Cross-sectional and longitudinal studies. Med Teach. 2010;32:e143-e151.

4. Svirko E, Golacre MJ, Lambert T. Career choices of the United Kingdom medical graduates of 2005, 2008 and 2009: Questionnaire surveys. Med Teach. 2013;35:365-375

5. McDonald $\mathrm{P}$, Jackson $\mathrm{B}$, Alberti $\mathrm{H}$, Rosenthal J. How can medical schools encourage students to choose general practice as a career? Br J Gen Pract. 2016;66:292-293

6. Mansour S, Alberti H. What factors influence British medical students' career intentions? A primary care response. Med Teach. 2015;37:702

7. Ibrahim M, Fanshawe A, Patel V, Goswami K, Chilvers G, Ting M, Pilavakis Y, Rao C, Athanasiou T. What factors influence British medical students' career intentions? Med Teach. 2014;36:1064-72

8. Querido SJ, Vergouw D, Wigersma L, Batenburg RS, De Rond MEJ, Ten Cate OTJ. Dynamics of career choice among students in undergraduate medical courses. A BEME systematic review: BEME Guide No. 33, Med Teach. 2016;38:18-29

9. Merrett A, Jones D, Sein K, et al. Attitudes of newly qualified doctors towards a career in general practice: a qualitative focus group study. Br J Gen Pract 2017; DOI: https://doi.org/10.3399/ bjgp17X690221.

10. Alberti H, Carlin E, Harrison M. What factors influence intention towards a career in general practice? (letter). Br J Gen Pract 2017;68:253 